\title{
Can Education System be Repaired? Ideological Dearth in Kenya's Educational Practice and its Implications for Reforms in the Education Sector
}

\author{
Amukowa Wycliffe \\ School of Education \\ Mount Kenya University, Kenya \\ Email:kwamukowa@yahoo.com \\ Gunga O. Samson \\ Department of Educational Foundations \\ University of Nairobi, Kenya \\ gungasamson@googlemail.com \\ Vihenda Caroline Ayuya \\ Department of Psychology \\ Daystar University \\ ayuyac@yahoo.com
}

Doi:10.5901/jesr.2013.v3n2p213

\begin{abstract}
This paper confronts two issues; reforms (repairs) and ideology in education. Machines can be repaired any time they breakdown or develop defects. Educational reforms have been carried out any time an emerging need has to be confronted. Can these education reforms be seen as repairing an education system? Ideology on the other is a coherent system of ideas; relying upon a few basic assumptions about reality that may or may not have any factual basis, but are subjective choices that serve as the seed around which further thought grows. When traditional societies began to undergo changes, the ritualistic legitimization of education gave way to a new type of legitimization - the ideological legitimization of education. The latter has two attributes: one involves the appearance of people's recognition of their right to choose the type of education that suits their tastes, values, aims and understanding. In view of this new realization, they no longer feel obliged to the accepted education only because it is the accepted type. The second attribute requires the simultaneous existence of several conceptions of education, from which one may choose the type of education suitable to one's needs. This paper searches into the possibility that there are no longer ideologies necessary to guide educational practice in Kenya, thereby raising concerns over education relevance.
\end{abstract}

Key Words: Education, Ideology, Reforms

\section{Introduction}

The question of education relevance has seen Kenya's preoccupation with reforms in the education sector since the introduction of Western system of education in the 1800s. There are concerted efforts towards reforms to respond to social and economic needs in the interest of the Kenyan people. These reforms have been informed by various world declarations on education such as the Universal Declaration of Education as a Human Right in 1948 by the United Nations, the international protocol that established Education for All (EFA) agenda in Jomtien, Thailand, 1990 and the World Education Forum (WEF) in Darkar, Senegal, 2000. 
According to the Kenya Ministry of Education (www.education.go.ke/showPage.aspx? Department \& id=1164), Kenya Vision 2030, a blue print of the Kenya's aspirations by the year 2030, singles out education and training as the vehicle that will drive Kenya into becoming a middle-income economy. In addition, the Constitution, 2010 has provided for free and compulsory basic education as a human right to every Kenyan child. It is because of this that the Government set a task force in January 2011 to realign the education sector to Vision 2030 and the new Constitution.

The Task Force (TF) identified specific issues including relevance with regard to content and delivery; sufficient flexibility to adapt to the changing socio-economic needs and requisite quality to match global competitiveness and to address challenges of the 21st century. Other issues were effective governance and management; retention and transition rates at various levels; teacher education, management and attrition; effective structure; Standards and Quality Assurance; Monitoring and Evaluation; access especially to the vulnerable and a sufficiently flexible and responsive regulatory framework to deal with the current and emerging challengesand ensure total access, equity and quality (www.education.go.ke/showPage.aspx? Department $=\mathrm{I} \& \mathrm{id}=1164)$.

The TF noted that the current quality of education was not clearly spelt out so that the curriculum delivery could focus on development of specific expected competences to be assessed. In view of this, it was found necessary to recommend a more flexible and comprehensive structure for Kenya's education system and curriculum reform to specify the expected competences at every level of learning. The Task Force recommended major reforms of the curriculum to align it with the Constitution and to ensure that the aspirations of Vision 2030 are met; Structure the curriculum within a skills and competences framework that identifies the knowledge, skills and competences all learners will acquire, and which will provide both vertical and horizontal coherence.

This paper argues that the educational reforms being implemented by the Kenya Government would be more appreciated by her people in the event that they are guided by a general ideology. Such an ideology would form a coherent system of ideas, relying upon a few basic assumptions about the practice of education in Kenya around which further thought on education would grow. This way, the Kenyan people would have recognition of their right to choose the type of education that suits their tastes, values, aims and their understanding. Likewise, they would no longer feel obliged to the accepted education only because it is the accepted type but rather, because they have several conceptions of education, from which they may choose the type of education suitable to them.

\section{Ideology: An Overview}

Wikipedia presents an ideology as a set of ideas that constitute one's goals, expectations, and actions. An ideology can be thought of as a comprehensive vision, as a way of looking at things. The main purpose behind an ideology is to offer either change in society, or adherence to a set of ideals where conformity already exists through a normative thought process.

(...) ideology is a coherent system of ideas, relying upon a few basic assumptions about reality that may not have any factual basis, but are subjective choices that serve as the seed around which further thought grows. (...) ideologies are neither right nor wrong, but only a relativistic intellectual strategy for categorizing the world.

According to Meighan and Siraj-Blatchford (1997), an ideology is a broad interlocked set of ideas and beliefs about the world held by a group of people which they demonstrate in both behaviour and conversation. These systems of belief are usually seen as the way things really are by the groups holding them, and they become the taken-for-granted way of making sense of the world. Lamm (n.d) observes that ideologies are cognitive systems that serve man in discovering and inventing the meaning of the world and of life, and to derive an orientation for his actions. They (ideologies) bestow meaning to their (people) lives and direct their actions, each in its own way, none encompassing all areas of life. Ideologies act as a control mechanism on people's actions in their social and political lives. The assumption is that ideologies can fillthis role of control mechanisms because people cannot control their ideologies tothe same extent that they can control their scientific research, their philosophicthinking or their practical actions. People see ideologies as their viewpoint of 
choice, set of ideas or methods of thought that they have rationally chosen when deciding among available alternatives.

Lamm (n.d), discusses that a comprehensive ideological expression has four components, differing from each other in the types of human abilities that create them. These components are: diagnostic, eschatological, Strategic thinking and a definition of certain publics. Diagnostic component present in every ideology is composed of propositions answering the question "what is?" What defines a proposition asdiagnostic is its content, answering the question "what is?"and the structure fitting this content. The second component of every ideology is the eschatological one. The propositions composing it answer the question "what should be?" The third component of each ideology includes propositions telling us what we should do in order to make the available that is the content of the diagnosis, into the desirable, that is into the eschatological. This component includes a choice of one of the possible strategies: to strive for the desirable by means of information and education, political action, revolution and a seizure of power, or by other means. Strategic thinking leading to a choice of one of the alternatives of action is vital to people in all their actions. The fourth and last component of every ideology includes a definition of certain publics, and answers the questions "for whom?" and "by whom?" One public is defined in each ideology as its carrier, the public meant to realize it; another public is that on whose behalf the first group acts.

According to Lamm (n.d), each of the four components of ideology also serves man outside the ideologies. People try to answer the diagnostic questions in their scientific and practical life. They strive for the ideal of the desirable in their moral, religious, utopian thought; try to solve many practical problems through the use of various strategies; and identify with several publics, such as their family, the inhabitants of their area of residence, their church, their culture or humanity as a whole. When the four components coalesce, they form an ideology; and in their coalescence, each loses its original characteristics. Diagnosis in an ideology is no longer such as in science or practical action. It is affected by eschatology that is the longing for the desirable; by the previous choice of strategy and of preferred publics. A diagnosis influenced by what man desires, by the method of action acceptable to him, and by what fits with his belonging to a certain group or with his identification with it, is not a proper diagnosis but a thought derived from aspirations. This is alsotrue for each of the other components, affecting the diagnosis and affected by it andby all the other components. The coalescence of these four components forms an ideology that constitutes a consolidated structure not easily dissoluble, and resistant to changes. Even a partial change in one of the components creates a new ideology.

The diagnosis, the eschatology and the publics are identical in the communistic and socialistic ideologies. These ideologies differed in their time only as to their decisions on the best strategy. Because of these differences, it means that the agreement about goals was forgotten, as well as about evaluating the situation and about the public on behalf of which they both wanted to act. The rich history of ideological controversies has not produced many examples of such acute rivalry as between the followers of these two close ideologies. This rivalry came about because ideological strategy is not only a decision about means, but is an inseparable part of the whole ideological structure.

\section{The epistemological meaning of ideologies}

Lamm (n.d), discusses that a comprehensive ideological expression has four components differing from each other in the types of human abilities that create them. These components are: diagnostic, eschatological, strategic thinking and a definition of certain publics. Diagnostic component present in every ideology is composed of propositions answering the question "what is?" What defines a proposition asdiagnostic is its content, answering the question "what is?" and the structure fitting this content. The second component of every ideology is the eschatological one. The propositions composing it answer the question "what should be?" The third component of each ideology includes propositions telling us what we should do in order to make the available that is the content of the diagnosis into the desirable that is into the eschatological. This component includes a choice of one of the possible strategies: to strive for the desirable by means of information and education, political action, revolution and a seizure of power, or by other means. Strategic thinking, leading to a choice of one of the alternatives of action, is vital to people in all their actions. The fourth and last component of every ideology includes a definition of certain publics, and answers the questions "for whom?" and "by whom?" 
One public is defined in each ideology as its carrier, the public meant to realize it; another public is that on whose behalf the first group acts (Lamm (n.d).

Each of the four components of ideology also serves man outside the ideologies. People try to answer the diagnostic questions in their scientific and practical life. They strive for the ideal of the desirable in their moral, religious, utopian thought; try to solve many practical problems through the use of various strategies; and identify with several publics, such as their family, the inhabitants of their area of residence, their church, their culture or humanity as a whole.

When the four components coalesce, they form an ideology; and in their coalescence, each loses its original characteristics. Diagnosis in an ideology is no longer such as in science or practical action. It is affected by eschatology that is the longing for the desirable; by the previous choice of strategy and of preferred publics. A diagnosis influenced by what man desires, by the method of action acceptable tohim, and by what fits with his belonging to a certain group or with his identification with it, is not a proper diagnosis but a thought derived from aspirations. This is alsotrue for each of the other components, affecting the diagnosis and affected by it and by all the other components. The coalescence of these four components forms anideology that constitutes a consolidated structure not easily dissoluble, and resistant to changes. Even a partial change in one of the components creates a new ideology (Lamm (n.d).

The diagnosis, the eschatology and the publics are identical in the communistic and socialistic ideologies. These ideologies differed in their time only as to their decisions on the best strategy. Because of these differences in means the agreement about goals was forgotten, as well as about evaluating the situation and about the public on behalf of which they both wanted to act. The rich history of ideological controversies has not produced many examples of such acute rivalry as between the followers of these two close ideologies. This rivalry came about because ideological strategy is not only a decision about means, but is an inseparable part of the whole ideological structure.

\section{Ideology and Education}

Lamm (n.d) argues that when traditional societies began to undergo changes, the ritualistic legitimization of education gave way to a new type of legitimization; the ideological legitimization of education. The latter has two attributes: one involves the appearance of recognition of their right to choose the type of education that suits their tastes, their values, their aims and their understanding. In view of this new realization, they no longer feel obliged to the accepted education only because it is the accepted type. The second attribute requires the simultaneous existence of several conceptions of education, from which one may choose the type of education suitable to one's needs. When people recognize their right to choose the education suitable to them (and no longer to act according to accepted tradition) and when different educational conceptions are available to them, then begins the modern era in education - the era of ideological legitimization of education:

(a) Ideologies are cognitive systems that clarify to people the essence and aims of education, and the criteria by which people choose the type of education they prefer over others; (b) Ideologies are social control mechanisms, by means of which agreement is reached in various societies about the accepted ways of educational practice, through which these societies try to ensure their continuity. Clarification of the connection between the ideologies as cognitive systems used by individuals and as social control mechanisms, and between educational thought, requires that we first note their structure and the connection between them and their function (Lamm n.d; 2).

\section{Overview of Education Reforms in Kenya}

According to Stanfield (2005), the European model of schooling was introduced in Kenya towards the end of the nineteenth century with the first school opened by the Christian Missionary Society near Mombasa in 1846. While few schools were built further inland until the turn of the century and the building of the Uganda railway, it is estimated that mission schools had been established throughout Kenya by 1910. In response to the increasing demands for education, the colonial authorities established a Department of Education in 1911 and missionary societies began to receive government grants to help fund the building of new schools. However, only those schools which adhered to the principles set out in the 1909 Fraser Report qualified for government 
funds. Therefore, while academic education was to be given to European and Asian children, African children were to receive industrial and agricultural training. Christian teaching became compulsory and African customs and traditions were subsequently neglected. Furthermore, African children were barred from learning English until the last year of primary school. This marks the beginning of the calls for education reforms in Kenya.

Ojiambo (2009) discusses that the aftermath of the First World War saw a number of government measures with regard to African education. During this period, the colonial government ended it's hitherto spectator status and initiated a system of grants-in-aid immediately after establishing the Department of Education in 1911 to help in the development of education provided by Christian missions. It also appointed East Africa Protectorate Education Commission in 1919 to review education provided in the colony for all races. According to Achola and Pillai (quoted in Ojiambo 2009), The East Africa Protectorate Education Commission was mandated to look into unsatisfactory status of education for all races in the protectorate. The commission made a vague recommendation to the effect that while the provision of education would remain a major responsibility of the missionaries, the government should increase its provision role. During this period, the Phelps-Stokes Commission of 1912-1925 also visited the colony. The reports of these two commissions formed the backbone on which Kenyan education was cemented during this phase. According to Sifuna and Otiende (1992) key aims of the report was to make the individual efficient, promote and advance agriculture, develop native industries, improve health, train people in the management of their affairs and the inculcate citizenship and service.

According to Ojiambo (2009), some of the key commissions that were undertaken to review education during this period included: a Ten Year Plan, Phelps-Stokes Commission of 1924, the Beecher report of 1949, and the Binns Commission of 1952. A Ten Year Plan sought to provide $50 \%$ of school age children with an education lasting six years and to offer within ten years a full primary course for undergraduate teachers to ensure that there was adequate supply of trained teachers. In addition, a satisfactory number of pupils of both sexes were expected to receive education up to the certificate level. The plan however, was not implemented for the whole cost was to be borne by local government authorities that had inadequate finances. The Commission advocated for both quantitative and qualitative improvement of African education. One objective of this qualitative improvement was to give Africans academic type of education similar to that available to European and Asian children. It recommended a practically oriented education for Africans. This was reinforced further by the permanent Advisory Committee on Native Education in Tropical Africa that was set up by the British colonial Africa office. Its purpose was to develop rural areas. It advocated for continuity in policy and fuller cooperation between governments and missions.

While referring to the observations made by Bogonko (1992), and Sifuna (1990), Ojiambo (2009), argues that although the Commission was expected to create avenues that could make Africans have more access to education and national development, this was note the case. Education during this period remained racial. Europeans and Asians had an education that laid more emphasis on academics and aimed at preparing them for white-collar jobs while Africans on the other hand received an education that geared them towards manual labor. Although the commission made some important contributions in teacher education it failed to meet Africans personal goals and paid little attention to affective domains of education. Most Africans did not want the type of education it was propagating and thus rejected it. They yearned for an academic education that was not racial and one that could promote development. Because of its inadequacies many Africans opted to set up their own independent schools.

According to Otiende et al (1992), The Beecher Committee of 1949 was mandated to examine the scope, content, methods, administration and financing of African education. Ojiambo (2009), mentions that the report reinforced the argument of Phelps- Stokes and the Ten Year Developmental plan on the provision of practical education to Africans. Its recommendations formed the basis of the government policy on African education until the last year of colonial rule. According to Bogonko (1992), Africans were strongly opposed to the Beecher Report the recommendations were viewed as leading to Europeanization rather than Africanization of education in which it sought to maintain the status quo of perpetually keeping Africans in low cadre positions.

According to Eshiwani (1992), the British Secretary of State set up Binns Commission in 1952 to examine educational policy and practice in British Tropical African territories. Ojiambo (2009), discusses that the Binns Commission was mesmerized by the high level of wastage within the education sector. According to Sifuna \& Otiende (1995), the Binns commission was significant in Kenya's education because it expressed concern 
regarding the internal efficiency of African education and its ability to address their needs. The colonial government also passed three major education ordinances in 1921, 1931, and 1934 and set up several educational committees, councils and boards aimed at improving the quality of African education (Bogonko, 1992).

Ojiambo (2009), discusses that in the mid 1950s, the colonial office realized it needed a new policy of education. This led to the drawing up of a developmental plan. The plan advocated for speeding up of output of high-level African workforce by expanding secondary and higher education. Within five years the pace of education was enormously increased for there was anticipation of African rule that required training of more manpower. Sifuna (1992) and Bogonko (1992), observe that the colonial education policies, even after the 1950s, continued to favor European population in terms of finance, curricula and structure and the African education was always the residuary legatee of the wealth of the state. Moreover, only a small number of African children went to school and the rate of attrition was very high compared to European and Asians. The openings for post-primary education for the Africans were also limited and those Africans who qualified were restricted by the many examinations they had to undertake (Bogonko, 1992). An examination of educational reforms undertaken during this period depicts colonial government efforts of using education to foster development that was racial.

According to Ojiambo (2009), historical Development of Kenya's Education System in the Post- Colonial Period and Kenya's struggle for political independence served as a major impetus for her educational development. During the struggle for independence, the nationalists' educational aim was to provide an education that would serve immediate needs of the country. In 1961, when independence was imminent in most African countries, a conference on the development of education in Africa was held in Addis Ababa, Ethiopia and Tananarive in Madagascar in 1962. In these two conferences, representatives from all over Africa set educational priorities that aimed at promoting economic and social development. It was upon this framework that Kenya like other African governments formulated its educational programs.

Sifuna \& Otiende (1995), point out that the expansion and reform of the education system during this period was motivated by political pressures. Almost every politician and election manifesto leading to the independence elections had called for more educational opportunities of all types, cheaper or free education, universal primary education, Africanisation of syllabuses and teaching staff and an atmosphere in which the African personality and culture could flourish. The education system was expected to fulfill two main objectives: technical and social. The technical objective was to provide future human resource with necessary skills and knowledge, and the social purpose was to inculcate values that could enrich people's lives and maintain cohesive sensibilities. In line with this thinking most African countries devoted their early educational policies to training personnel that could man their burgeoning economic and administrative units.

Ojiambo (2009) notes that Kenya embarked on various educational legal policies that could advance its development. The first undertaking by the government was the drafting of Sessional Paper Number 10 in 1965. This served as an important document for examining immediate needs and goals of post-independence Kenya. The paper saw education much more of an economic than a social service, a key means of alleviating shortage of skilled domestic workforce and of creating equal economic opportunities for all citizens (Republic of Kenya, 1965b). During this period the government established five major inquiries to look into the development of Kenyan education: The Kenya Education Commission-Ominde Commission(Republic of Kenya, 1964, Republic of Kenya, 1965a, Republic of Kenya, 1965b), The National Committee on Educational Objectives and Policy- Gacathi Report ( Republic of Kenya1978), The Presidential Working Party on the Second University-Mackay Report (Republic of Kenya, 1981a), The Presidential Working Party on Education and Man-power -Kamunge Report ( Republic of Kenya, 1988) and Commission of Inquiry into the Education system of Kenya- Koech Commission (Republic of Kenya, 1999).

Eshiwani (1992), points out that Ominde Commission outlined what education was and had to be during and after independence. It was the blueprint that laid the foundation of post-independence education. It was mandated to survey existing educational resources and to advise the government on the formation and implementation of the required national policies for education. The commission was strongly influenced by the then existing international opinion, economic and political forces and available publications that underscored the importance of education in accelerating national development. Ojiambo (2009), points out that the organization of education during this period was closely linked to the management of human resources and the 
labor market. This link led to the growth of enrollments, especially in secondary schools, a growth that continued to be experienced in the 1980s. Although formal education was expanding during this period, it was not directly accompanied by the economic growth. Thus, most school dropouts were soon left out with neither jobs nor training. By 1970, majority of secondary school drop outs began to experience unemployment crisis. Due to increase in demand for higher education and the need for highly qualified manpower, the government made more acts in the 1980s geared towards the improvement of education to enable it spearheads development.

While making a critical examination, Ojiambo (2009), argues that the various educational acts that were undertaken during this period illustrate the government's commitment to improving education and the emphasis it placed on its ability to develop the nation. It is important to note that despite its noble objectives the Ominde Commission recommendations were not implemented in full, a blunder that has had significant effects on education. Amutabi writes that if the first Ominde Commission Report would have been implemented in full... Kenya would not have been wandering and experimenting with dubious systems like 8-4-4 today. The Gacathi Report reiterated objectives of the Ominde Commission and sought to enhance the use of the Kenyan educational goals to shape its national character and development. It recommended vocational, technical and practical education (Republic of Kenya, 1964a; Republic of Kenya 1965b). In 1975, the government realized that education was not doing much to achieve its stated objectives. Education curriculum was viewed as being too academic, narrow and examination centered (Republic of Kenya, 1979b; Republic of Kenya 1980). Rate of unemployment grew as school leavers went to urban centers to seek for white-collar jobs. This led to the formation of the third development plan of 1974/78 to address some of these challenges (Republic of Kenya, 1979b). Education system during this period was required among other things: to provide high level skills needed for economic, industrial, vocational and technical training that was essential for employment and development.

In the 1980s the government changed its policy on education. This was because of the difficulties which were being faced by graduates of its education system at both primary and secondary levels. Most graduates who were matriculating from these levels could not be absorbed into the shrinking labor market. This made the government to reconsider changing its education system and to set up a Presidential Working Party in 1981 (Republic of Kenya, 1981a). The report sought to investigate ways in which education could make graduates from these levels self-sufficient, productive in agriculture, industries and commerce. Education system was expected to ensure that students acquired technical, scientific and practical knowledge vital for self and salaried employment, lifelong skills and nation building. The commission was also mandated to investigate the feasibility of establishing a second university that was development centered. It advocated for a practical curriculum that would offer a wide range of employment opportunities and equitable distribution of educational resources. It gave rise to the current education system, the 8-4-4 (Republic of Kenya, 1988).

The current educational curricula, commonly referred to as the 8-4-4 system, consists of eight years of primary education, four years of secondary, and four years of university education. According to Sifuna (1990), there are three events that led to implementation of the 8-4-4 system: the 1966 conference on education at Kericho in Kenya, which stressed the need for integrating rural development; the International Labor Organization mission report entitled "Employment, Incomes and Equality: A Strategy for Increasing Productive Employment of 1972;" and the recommendation of the National Committee on Educational Objectives and Policies of 1975. In 1979, the Ministry of Education was changed to the Ministry of Basic Education with an introductory nine-year basic education system program. The rationale was that the previous program was too short and not rigorous enough to give graduates enough practical education. It also recommended that the first six years of primary were to concentrate on numeracy and literacy skills and the last two years on basic education with practical orientation. This represented a shift from a focus on enrollment to restructuring the program as a means to cater to the influx of unemployed.

The implementation of 8-4-4 system of education has been suspiciously viewed. For instance Ojiambo (2009), remarks that:

An in-depth examination of the rationale for introducing the 8-4-4 system gives a hidden agenda. Available evidence seems to suggest that the change of the system was more political than an educational need (...)the system was introduced partly as result of the Mackay Report and also as a political self-actualization by the government (...) inherent in the system was a hidden motive of an apparent settling of some imbalance and 
political scores. The concept of the 8-4-4 system of education was therefore from the beginning politically driven and there was no major crisis to warrant the change of the system (...).Ojiambo (2009)

\section{Kenya's Educational Ideology}

Kenya's education ideology could be understood as a set of ideas which constitute or have constituted/ contributed towards the goals, expectations, actions and practice of education. This way, such ideology could be discussed within several stages/periods of educational developments and its (ideology) dearth established.

\section{The Colonial Era: Assimilation and Adaptation Ideology}

An overview of the history of education shows that missionaries introduced Western education in Kenya. The first missionaries to settle on the East African coast were Portuguese Roman Catholics. By 1557, they had established monasteries at Mombasa and Lamu, Kenyan coastal towns. The second wave of Christian missionaries included the Lutherans, who were sent to Kenya through the Church Missionary Society (CMS). Among these were Johann Ludwig Krapf, Johann Rebman, and Jacob Erhadt. The partition of Africa in 1884 established British rule in Kenya and led to an increase of Christian missionaries. As the missionaries established themselves on the mainland, they started schools as a means of converting Africans to Christianity. Their acceptance was somewhat due to the fact that they used the schools as a means of rehabilitating slaves who were returned after having been captured by Arabs.

In 1908, the missionaries formed a joint committee on education that later became the Missionary Board of Education, representing all the Protestant missions in the British protectorate. In 1909, the British government established an education board with Henry Scott of the Church of Scotland serving as the chair. The establishment of the education board occurred at the same time that the Fraser and Giroud Commissions were put in place. These commissions called for racial consideration in developing the British protectorate. The recommendations included a push for industrial development, technical education, and the teaching of religion as a moral foundation.

After the First World War, a more concerted effort by the British to develop African colonies was established. The British began reexamining and reevaluating education in the African territories. In 1923 the British secretary of state established a committee chaired by the parliamentary under-secretary of state to advise on the educational affairs of the African-Kenyans. This marked the beginning of the first educational policy by the British colonial government. This period marked the beginning of the three-tier education system in Kenya. There were racially segregated schools for Europeans (whites), Asians, and Africans.

James Stanfield (2005), points out that only those schools which adhered to the principles set out in the 1909 Fraser Report qualified for government funds. Therefore, while academic education was to be given to European and Asian children, African children were to receive industrial and agricultural training. Christian teaching became compulsory and African customs and traditions were subsequently neglected. Furthermore, African children were barred from learning English until the last year of primary school.

An understanding of the practice of education at this time was that it was the means by which Africans were to be transformed to accept the way of life of the Europeans. Africans were to learn the language and moral values of the Europeans. This way, the underlying ideology in the practice of education was to have Africans assimilate and adapt to European values.

The Independent School Movement: Influence of Assimilation and Adaptation Ideology on Education Practice in Kenya

According to James Stanfield (2005), following a ban on female circumcision by three missionary societies in 1929, the Kikuyu in CentralProvince began to boycott mission schools and demanded an end to the monopoly on education held by the missions. After failing to persuade the government to open its own secular schools free from missionary control, the Kikuyu began to open their own.

During the early 1930s extensive fundraising activities took place, school buildings were erected and selfhelp groups formed. Each independent school was governed by a local committee, responsible for the recruitment and payment of teachers, the setting of school fees and other fundraising events. As independent 
schools became established joint meetings were organized and at a gathering in August 1934 the Kikuyu Independent Schools Association (KISA) was set up. While KISA emphasized the need to negotiate with the colonial authorities, some independent schools wanted to remain entirely free from direct European influence. A rival association, the Kikuyu Karinga Education Association (KKEA), was therefore established soon after. By 1939 there were 63 Kikuyu independent schools educating a total of 12,964 pupils.

To help meet the increasing demand for trained teachers both KISA and KKEA agreed to support the opening, in 1939, of Kenya's first teacher-training college at Githunguri, the site of the Kikuyu's first independent school. Originally intended to train teachers, the College soon included an elementary, primary and secondary school, with enrolments increasing to over 1,000 by 1947 . As James Stanfield (2005), noted these findings help to shed light on the importance of independently controlled schools in a free and democratic society. In Kenya's struggle against colonial rule it was their schools which first gained independence providing the momentum for future reforms. On becoming President of Kenya in 1964, Jomo Kenyatta championed the Harambee spirit of self-help which he believed the future development of Kenya would depend upon.

\section{Independence (Kenyatta Era) and 7-4-2-3-System of Education: Education for Manpower Development Ideology}

According to Kivuva (2002), Kenya's attainment of independence from Britain in 1963 was a great source of hope to her people, for it marked an end to the stings of long suffering and discrimination. The independent Kenya therefore needed to make changes in different areas in order to reflect the needs of her people. Education was one of such areas that required such changes, given the way it was operated during the colonial regime.

The first changes were achieved through the Ominde Commission Report of 1964 (Republic of Kenya, 1964). The Ominde Commission became the first educational committee in the independent Kenya to look into the educational issues that affected the country and made recommendations for what they considered to be appropriate changes. Among the changes, were the adoption of 7-4-2-3 structure- seven years primary, four years of lower secondary, two years of upper secondary and three years of university education (Republic of Kenya, 1964). Simiyu (1990), observed that other changes include the content of subjects such as history and geography in an attempt to build a national identity and the abolition of technical and vocational education in primary education.

According to (Rharade, 1997), Ominde underscored the need to reform the education system so that it became a way of changing people's attitudes and a means of establishing social equality. Education was seen as a gateway to training the highly-skilled staff that Kenya needed and was viewed as a productive investment, not only to the individual but also to the society as a whole. Rharade, (1997) points out further that the Ominde Commission influenced the view of education as an instrument for development. The organization of education, therefore, was closely linked to the management of human resources and the labor market. This view of education, which was influenced by the human capital theory, led to the growth of enrollments, especially in secondary schools; it was a growth that continued to be experienced even in the 1980s (Kivuva, 2002). Through education, there was a chance for individual mobility and a good life.

\section{Reforming the 7-4-2-3- System of Education: The Failure of Education for Manpower Development Ideology}

Owino (1997) argued that the call for reforms in the 7-4-2-3 system of education in Kenya was widespread and based on the perceived weakness of such educational policy. It was observed that the system lacked the capacity and flexibility to respond to the changing aspirations of individual Kenyans and the labour market needs, in terms of new skills, new technologies and the attitude to work. The deficiencies of this educational ideology manifested itself through the increased number of school leavers who went through primary and secondary education but were unemployed at the end because they either lacked the specific skills required for wage employment/self-employment or because the leavers were selective about the type of jobs they thought they had been prepared for (Owino 1997).

According to Sifuna and Otiende (1992), the Presidential Committee (1982/83) on unemployment noted that one of the factors, which contributed to unemployment, was the type and quality of education, which was being imparted in schools. The Presidential Committee further noted that the subjects, which were taught at both primary and secondary schools, were heavily biased towards intellectualism and lacked the development of 
adaptive skills and lacked the technical and vocational component and was therefore accused of being highly academic.

Simiyu (2001), observed that the 7-4-2-3 system of education was criticized in two major areas. First was that the system was being too academic and therefore not suitable for direct employment thereby lacking orientation to employment. Second, it was argued that the system encouraged elitist and individualistic attitudes among school leavers, an aspect that was considered incompatible to the African socialist milieu. Unemployment concerns with regard to the 7-4-2-3 system of education were conspicuously mentioned in The Gachathi Report of 1976. The Report noted that:

(...)One of the largest problems confronting the country is that of unemployment. The problem is aggravated by the annual outputs of school leavers whose number continue to swell following the enormous expansion of the education system in the first years of independence (...) Unemployment which was said to have started among primary school leavers had spread to embrace even university graduates (Republic of Kenya, 1976:3334).

As Kivuva (2002) observes, education, which was regarded by Kenyans as a medium for social mobility and national economic development failed to deliver as the number of unemployed school leavers continued to grow. In a sense the 7-4-2-3 system was regarded as a failing tool for national development. Therefore a change of the system was required. According to Maleche (1970), the Kenya National Assembly's Select Committee on unemployment (1970), made calls for change of education system to address unemployment noting that:

Of fundamental importance to the solution of unemployment problem will be a reform of content and scope of educational curricula in the nation's education system. The present circular are too exclusively academic. The school-leavers cannot apply their knowledge to farming or to other activities like bookkeeping, masonry, and carpentry and joinery. The school curricula should therefore be revised to give them a more practical bias. Teaching on agriculture and practical skills should be established both at primary and secondary schools (Maleche, 1976:13)

Eshiwani (1992) noted that to address the problem of unemployment, the government proposed an emphasis on technical education so that those who were not able to go on to secondary school could receive training that might lead them to either self-employment or other jobs in the non-formal sector. In 1975, the National Committee on Educational Objectives and Policy (NCEOP) was formed and was concerned with the issue of unemployment. Eighty percent of primary school dropouts were jobless at that time. The committee's task was to review the achievements of the educational objectives after more than a decade since independence. This led to the Gachathi report of 1976

The Gachathi report of 1976 emphasized the provision of free primary education. The report also noted that there was need to integrate secondary education with the non-formal sector in order to take care of school dropouts. This called for the introduction of more technical subjects in secondary schools. The last grade in higher secondary education (Form 6) was to be a major recruiting stage, since only a few students could be absorbed by Kenya's only university.

According to Kivuva (2002), institutions for vocational training were seen as an answer to the problem of unemployment. Many religious organizations started vocational training institutes, but the enrollment remained low. Still, few people were in favor of blue-collar jobs. There were moves towards vocational education, although such programs remained unpopular with school dropouts at all stages. The 7-4-2-3 system, as the tool of national development was seen as failing.

\section{Post Independence Period (Moi Era): Education for Self-Reliance ideology}

As discussed in the preceding sections of this paper, education, viewed by Kenyans as a vehicle for social mobility and national economic development, was not serving these purposes as the number of unemployed school-leavers rose. According to Makori (2005), as early as the 1970s, the ILO report showed that there was a need to make changes to the education system in order to help reduce unemployment. The ILO recommended increasing the technical aspect. The first and second United Nations' (UN) "development decades," the 1960s 
and 1970s, also influenced the educational plans most third-world countries made after independence. The UN's main aim was to focus on the production of skilled manpower, reducing social inequalities and providing basic education for all. The move by ILO towards vocationalizing education was supported by the World Bank. Thus, technical and vocational training centers were established with financial aid from developed countries. The International Development Agency (IDA) was instrumental in the equipment of secondary schools.

Kenya also experienced problems associated with the 7-4-2-3 system in that the presence of Harambee schools led to inequalities in education. Most of them were closed due to a lack of funds, which meant that only the ones in the economically stable (mainly urban) areas could survive. Therefore, economic and regional disparities were evident. Gender disparities were also evident in the sense that, although at the primary-school level the difference had narrowed, girls were still not well-represented at the secondary school level. For example, in 1963, 23\% of girls attended secondary schools, while in 1980 the figure was $27 \%$, an increase of only $4 \%$.

Formal education was not solely to blame for this trend. Factors such as lack of qualified staff, centralization of management that allowed for little or no flexibility, and the rural-urban migration of qualified staff led to the dysfunction of the system. The problem of inequalities between boys' and girls' enrollment was more of a societal problem than an educational one, except for the fact that there were less state-funded secondary schools for girls than for boys, a fact that also reflects societal values. The issues discussed above all led to people's dissatisfaction with the education system. It coincided with a time when many secondary school graduates applied to join the university but could not get placed, due to the fact that there was only one university in Kenya at the time.

In 1981, the Presidential Working Party on the establishment of the SecondUniversity was commissioned to look at both the possibilities of setting up a second university in Kenya and of reforming the entire education system. The committee recommended that the 7-4-2-3 system be changed to an 8-4-4 system (eight years in primary, four years in secondary, and four years in university education).

\section{The 8-4-4 System of Education: Education for Self-reliance Ideology}

According to Muya (2000), the 8-4-4 system of education, which was pre-vocational in nature, was introduced in January 1985, following the Mackay report of 1982. King and McGrath (2002), report that:

(...) the 8-4-4 policy arose out of the concerns that a basic academic education might lack the necessary content to promote widespread sustainable (self) employment (...) King and McGrath (2002:89).

The 8-4-4 policy emanated from the assumption that it would equip pupils with employable skills thereby enabling school dropouts at all levels to be either self-employed or secure employment in the informal sector (Eshiwani, 1992). As King and McGrath (2002), observed the new system intended to orient youths towards selfemployment. The new policy would improve the student's employment potential and thus make them selfreliant (Amutabi, 2003).

According the Kenya Ministry of Education (1984) the 8-4-4 policy was designed to encourage students to become more self-reliant and better oriented towards self-employment. It contained a rather broad curriculum at both primary and secondary levels, with a strong emphasis on practical subjects sitting alongside a rather traditional approach to academic subject. Business education was introduced into upper primary as an evident of encouraging self-employment. As well as business education's focus on providing basic knowledge and skills on issues such as record keeping, there was a cross-curricular emphasis on attitudinal orientation towards selfemployment.

Eisemon (1988), observed that the Ministry of Education was charged with the responsibility of implementing the 8-4-4 policy under two task forces; the task force on curriculum implementation and the assessment of the cost of implementing the 8-4-4 curriculum. The task force in charge of assessing the cost of implementation submitted their report in late 1983, urging for caution and gradualism in implementing 8-4-4 system. The task force on curriculum implementation recommended that:

A structure ... should lead to the development of communication skills (literacy) through the teaching of mother tongue, English, and Swahili languages. The development of scientific outlook will be done through 
the teaching of mathematics, while the development of scientific outlook will be done through the teaching of integrated science. The development and acquisition of social and cultural knowledge, skills and attitudes will be done through the teaching of social studies, religious education, music and physical education, art, craft and home science will provide for practical knowledge and skills. (The Ministry of Education 1984:4).

\section{The 8-4-4 Educational Policy Confronted: Gaps in the Education for Self-Reliance ideology}

Although the 8-4-4 system curriculum allowed for more options in technical and vocational subjects, it experienced serious shortages or lack of essential resources and facilities and the local communities could not be mobilized to provide the facilities required. There were no trained technical and vocational subjects teachers and local craftsmen could not be used (Kerre, 1997; Simiyu, 2001). According to Amutabi (2003) the new system was theoretically oriented due to lack of infrastructure.

Desouza (1987), and Owino (1997) share the view that the crisis of unemployment of primary school leavers remained evident. Vocational subjects and activities were seen as an extra burden both in practical daily activities in schools and in national examination. According to King and McGrath (2002), the 8-4-4 system curriculum for primary school was also claimed to be overcrowded or overstretched. Therefore it was an obstacle to effective learning because the pupils worked under great pressure. Abagi (1997), noted that to cover an extended curriculum in the same period increased pressure to students and staff and thus reduced students performance (lower test scores). The pressure negatively affected the children's motivation to learn resulting in the rise in dropouts (Owino, 1997).

At the schools level, standard examination in agriculture, art and craft consisted of multiple-choice type of questions. Although this type of examination has the advantage of objectivity and easy marking, its validity to predict the leavers' ability in higher level of education training and employment was doubtful (Owino, 1997). Bedi et al. (2002), observed that by the time technical and vocational education was introduced within the 8-4-4 policy, there was a serious shortage of qualified teachers for vocational subjects. Many of the teachers were untrained, for instance untrained teachers (those with no formal teaching qualifications) increased sharply from $70 \%$ in 1990 to $96,6 \%$ in 1998), while some had been to teachers college but were not trained in the teaching of vocational subjects, they were thus limited in knowledge and pedagogy.

\section{The 2011 Education Reforms: Repairs and the Ideological Dearth in Kenya's Educational Practice}

As earlier mentioned in this paper, the Kenya Government's commitment to the provision of quality education and training to its citizens at all levels cannot be over emphasized. This way, the Government took some action that has created a lot of dialogue on the education sector in Kenya through the recommendations made by a Task Force set up in January 2011 to realign the education sector to Vision 2030 and the new Constitution. The TF identified a number of challenges, gaps and concerns which led to a pertinent question: "Is the Kenyan Education System and its institutions and programmes fit for the purpose?" This section makes a critical appraisal of the recommendations made by the Task Force while attempting to show some emerging ideological gaps.

\section{The Structure of Education, Curriculum and Assessment}

The Task Force noted that the current system of education, curriculum and assessment does not include Early Childhood Development and Education (ECDE). In addition, the quality of education was not clearly spelt out so that the curriculum delivery could focus on development of specific expected competences to be assessed. In view of this, it was found necessary to recommend a more flexible and comprehensive structure for Kenya's education system and curriculum reform to specify the expected competences at every level of learning. The recommended structure is 2 years of Pre-primary, 6 years of Primary (3 years lower and 3 years upper), 6 years Secondary (3 years junior and 3 years senior), 2 years minimum of Middle level Colleges and 3 years minimum University education. As a whole this structure will have two cycles; Basic Education cycle of 14 years which is free and compulsory, and a Higher Education cycle.

The rationale for the revised structure is to ensure learners acquire competences and skills that will enable them to meet the human resource aspirations of Vision 2030 by offering a choice of subject pathways at the end 
of the Elementary School phase; ensure the attainment of $100 \%$ transition rate from primary to secondary, thereby reducing wastage by introducing automatic progression to the junior secondary phase based on the acquisition of core skills and competences (literacy, numeracy and communication skills). The revised structure will also focus on early identification and nurturing of talent in individual learners at the end of the junior secondary phase; allow for specialization at the end of junior secondary; introduce a system of Competence Assessment Tests (CATS) measuring knowledge, skills and competences, the results of which will be cumulative and form part of a formative assessment process, the credits from which will be accumulated in the summative assessment at the end of each phase. This is distinct from the present situation where students either pass or fail and exit the system.

The recommendation to change the structure of education as proposed by the TF is actually an overhaul of the entire system of education. This way, the recommendation needs to be focused on a general need. For instance, in its proposal at the onset of independence, the Ominde Commission of 1964 identified the need for manpower development. The need to prepare and equip with relevant skills to close gaps in human resource development became the justification for the time spend in school and subjects/courses undertaken. In 1984, the Mackey Commission in recommending transition to 8.4.4 system, the justification for people to be selfreliant. This is after it was observed that the education system had outlived its Manpower development ideology hence the need to address unemployment. In a nutshell, it 8.4.4 was proposed as an avenue to address unemployment. Both Ominde and Mackey Commission received support from the political leadership that championed the ideology of education for manpower development and later education for self-reliance.

It is arguable that the TF did not identify an emerging need that education should address in Kenya. The rationale provided to change the structure of education system is in essence that of education for manpower development. According to Eshiwani (1992), illiteracy, poverty and diseases were the key principles that informed the recommendations of the Ominde Commission of 1964. In recommending for 2 years of Pre-primary, 6 years of Primary (3 years lower and 3 years upper), 6 years Secondary (3 years junior and 3 years senior), 2 years minimum of Middle level Colleges and 3 years minimum University education, the Task Force formed by the Kenya Government in 2011 argues that:

The rationale for the revised structure is to ensure learners acquire competences and skills that will enable them to meet the human resource aspirations of Vision 2030 by offering a choice of subject pathways at the end of the Elementary School phase; ensure the attainment of $100 \%$ transition rate from primary to secondary, thereby reducing wastage by introducing automatic progression to the junior secondary phase based on the acquisition of core skills and competences (literacy, numeracy and communication skills).

This paper argues that the rationale provided by TF has been addressed in Kenya since independence and that with the growing number of school enrollment, literacy and numeracy skills are no longer alarming problems in Kenya. This becomes more redundant particularly with the rising numbers of school leaver unemployment. This way, the TF's recommendations lack an ideology to form a coherent system of ideas around which further thought on education in Kenya would grow. As a result the proposed structure of education is a matter of repairing an old system built on education for manpower development.

\section{The New School Calendar, Term Dates Assessment and Evaluation}

It is recommended that the school year be divided into three terms of three months each as follows:

- Term I - September to November

- Term II - January to March

- $\quad$ Term III - May to July.

The TF noted that the months of July and August have minimal public holidays allowing for ample time for management of examinations. The unpleasant observation in this recommendation is the fact that whereas the Task Force to call for a system that is not much examination driven, it suggests an overhaul of the school calendar just give time for managing of examinations. This implies that the essence of education is examination. It translates into an import that the guiding idea behind this recommendation is "education for examinations." Indeed, the TF provided that: 
The revised structure will also focus on early identification and nurturing of talent in individual learners at the end of the junior secondary phase; allow for specialization at the end of junior secondary; introduce a system of Competence Assessment Tests (CATS) measuring knowledge, skills and competences, the results of which will be cumulative and form part of a formative assessment process, the credits from which will be accumulated in the summative assessment at the end of each phase. This is distinct from the present situation where students either pass or fail and exit the system.

On assessment and Evaluation, the TF noted that the current summative assessment at the end of every cycle does not measure learners' abilities. School-based assessments need to be strengthened so that regular and cumulative assessment in the form of Competence Assessment Tests (CATs) is put in place; the current education system is examination based and that the assessment has little regard to moulding good citizens and for self-reliance. There is need, therefore, to introduce competency-based assessment in line with a competency based curriculum. Revision of curriculum and textbooks is proposed to ensure skills and competences are emphasized. The TF noted that assessment is not seen as part of the teaching and learning process but as a sieve to determine those who can move to higher education where the limited available space dictates the teaching/learning process towards examinations as opposed to competences applicable to life.

Achievement at Kenya Primary Education Certificate (KPEC) level and Kenya Junior Secondary Education Certificate (KJSEC) would be considered in SeniorSecondary School admission and streaming. Schools would be ranked based on holistic assessment on performance indicators built around the following areas: academic, cocurricular activities, quality of management, operations and maintenance of physical facilities, environmental care, learners' services and community outreach programmes. The Cabinet Secretary will give a report on these indicators during a national education day. The process should start from institutions through the county to the national level. The Task Force recommends that KNEC is renamed the Kenya Educational Assessment Council (KEAC) and strengthened to address all matters related to management and administration of assessments in the country. Competency Assessment Tests (CATs) by teachers are to be supported with a national framework/guidelines or test-bank by KEAC to be made available online on a regular basis. These will make the CATs standard and de-emphasize the many private examination papers being sold all over the country. Management and administration of examinations leave room for malpractices.

It seems from this recommendation that key role of the proposed structure of education is to prepare learners for examination. The joy of knowing something is disregarded and only examination results matter. This, as Illich (1970) argued school programs hunger for progressive intake of instruction, but even if the hunger leads to steady absorption, it never yields the joy of knowing something to one's satisfaction. The fact that school calendar has to be changed to accommodate examination management attests to this observation.

As of 2012, there arose some serious issues relating to examinations results in Kenya. For instance, two former candidates and a head teacher committed suicide following poor performance in Kenya Certificate of Primary Education examination. Kabaji (2012) notes that the sad story of the two girls who committed suicide for failing to score their anticipated grades in the Kenya Certificate of Primary Education (KCPE) examination, reveals a lot, not only about the effects of a flawed education system, but also about our social system that has failed to capture the essence of education. A note left behind by one of the candidates sadly shows the lost hope, self esteem and fulfillment. The young girl had scored a total of 303 marks out of the possible total of 500 marks. She had aimed at 400 marks. According to Tirop \& Moraa (2012), the teenage girl wrote:

"Dear mum,

I have let you down in this world without scoring 400 marks."

The standardmedia.co.ke article notes that it is saddening to learn students still contemplate committing suicide for failing to attain top grades in national exams. However, one thing we must understand is that exam is not a life and death matter. There is no point of ending one's precious life due to poor results. This can be partly attributed to high societal expectations from candidates who feel disappointed once they fail to achieve the expectations. The article posts that:

Once results are out, as we embark on celebrating top candidates for working hard, a blame game ensues over who should take responsibility for poor performance among the rest of candidates. Unfortunately, it is the teachers and learners who received the largest share of the blame; parents, politicians and school sponsors 
hardly take responsibility for poor performance. (www.standardmedia.co.ke/letters/InsidePage.php?id ...cid $=17 \& 050175 . \mathrm{html}$ )

According to the Standard Newspaper, (www.standardmedia.co.ke/ Stop violence in schools over poor exam grades) parents pressure their children to score high grades, opportunities to get examination papers beforehand are grasped with relief and people are ready to pay anything for a leakage. Cheating is not only widespread but also condoned. When examinations are as overrated and students perform below expectations, egos are crushed and children's ambitions destroyed. A report carried by allafrica.com news has the following: Cheating is (...) cause of concerns for educators in terms of examination outcomes. In the year 2011 (Language of the year is edited original was: In last year's) KCPE, 334 exam stations reported cheating. Some 7,974 candidates out of the 776,214 who took the examination had their results cancelled, the worst cheating record in the history of KCPE (allafrica.com/stories/201201).

It seems therefore, that the recommendations made to change trends in examination and evaluation is geared towards dealing with the effects of examination in the society. This paper argues that regardless at what level and examination is taken and learner fails and has hope for the future, the problems will still remain. What is needed in this regard is an ideology that would guide students and the society at large, of what they can do with the examination/evaluation reports they get. This way, examinations would be an every day activity that informs people of their abilities and strengths, but not weaknesses and the seeming inability. For instance, a candidate should be able to know what to do with whatever marks or grade he/she gets and what she/he cannot do.

\section{Curriculum}

Aligning the curriculum to address the aspirations of the Constitution, Vision 2030 and the East African Community treaty was prioritized. It was proposed that the content for basic education should be designed with a view of equipping the learners with relevant knowledge that emphasizes on technology, innovation and entrepreneurship (Vision 2030), the development of their full capacities, living and working in dignity, enhancing the quality of their lives, making informed decisions and continuing with learning as a lifelong engagement.

The Task Force recommended major reforms of the curriculum to align it with the Constitution and to ensure that the aspirations of Vision 2030 are met; Structure the curriculum within a skills and competences framework that identifies the knowledge, skills and competences all learners will acquire, and which will provide both vertical and horizontal coherence. It also proposed for the development of a progressive assessment framework that identifies the knowledge, skills and competences that will be assessed for each level of education and called for the revision of the curriculum and textbooks to ensure skills and competences are emphasized as proposed.

This paper argues that the school/education curriculum carries the value disposition and experiences for the learners. The curriculum informs learners of their abilities upon which discovery of talents and careers are founded. Such curricular are informed by a wider ideology that confronts gaps and needs in people's daily lives. The Ominde Commission of 1964 that emphasized the Africanisation of the curriculum in Kenya had, for example, its foundation build on the need for cultural heritage and international image. This way, the Commission called for the teaching of vernaculars at the lower levels of education and compulsory learning of Kiswahili as Kenya's national language. Further, the Commission underscored the need for literacy and numeracy skills as efforts towards human resource development, hence emphasis on compulsory English and Mathematics. The Mackey Commission of 1984 while reflecting on the need to address school leaver unemployment underscored the need for practical skills hence the teaching of arts and crafts subjects in the early days of the 8.4.4 system. On the contrary, the TF makes recommendations on curriculum changes that do not address any common problem in the Kenyan society thereby lacking an ideology to attract support from the Kenyan masses.

\section{Conclusion}

This paper has underscored the place of ideologies in educational reforms. Ideologies, being a coherent system of ideas that rely upon a few basic assumptions about reality serve as the seed around which further thought on education grows. This way, ideologies inform people's recognition of their right to choose the type of education 
that suits their tastes, their values, their aims and their understanding and develop several conceptions of such education, from which they may choose the type suitable for them. It has further been shown that the current efforts to reform education in Kenya lack guiding ideologies hence having the import of repairing the education system. The need for an ideology to drive the Kenyan people on the role of education hence a suitable structure and curriculum is emphasized.

\section{References}

Abagi , O., and Olweya, J. (1999). Education reform in Kenya for the next decade: Implementing policies for adjustment and revitalization. Nairobi: Institute for Policy Analysis Research. Special Paper No. 3.

Achola. P., Pillai, V. (2000). Challenges of Primary Education in Developing Countries: Insights from Kenya. Aldershot: Ashgate, 2000.

Amutabi, N. (2003). The 8-4-4 system of education. International Journal of Educational Development. 23(2003), pp.127144. April, 2005.

Amutabi, N. (2003). Political interference in the running of education in post- independence Kenya: a critical retrospection. International Journal of Educational Development 23: 141.

Bedi, S., Kimalu, K., Manda, K., Nafula, N. (2003). "The decline in primary school enrolment in Kenya. KIPPRA Discussion paper No.14."URL://www.Kippr.org/Download DPN0.14.pdf (April, 2005).

Bogonko, S.N. (1992). A history of modern education in Kenya (1895-1991). Nairobi: Evans Brothers (Kenya) Ltd.

Desouza, H.S. (1987). Kenya education in its context. New York : Vantage Press Vol. 2 p.120.

Eisemon, T.O. (1988). Benefiting from basic education, school quality and functional literacy in Kenya. Oxford: Pergamon Press.

Eshiwani, G. (1992). Education in Kenya since Independence Nairobi. East African Educational Publishers.

Illich, I. (1970). Deschooling Society. London: Allen and Unwin

Kerre, B.W. (1997). The technical and vocational education for rural development: The case of Kenya. International project on Technical and Vocational education. UNEVOC.

Kivuva, A. (n.d). "Secondary education reform in Kenya: The quest for quality, relevancy, and equality." URL: http://www.ginie.org/cstudies/africa/es-africa.htm (15th May, 2005).

Lamm, Z. (n.d). Ideologies and Educational Thought. Jerusalem. Hebrew University of Jerusalem

Makori. A. (2005). "The Kenya's educational policy: Exploring some of the major impediments to redesigning pedagogy." A paper presented at the International conference (30th May to 1 June 2005: Nanyang Technological University, Singapore). University of Reading

Meighan, R., Siraj-Blatchford, I. (1997) A Sociology of Educating, London: Cassell

Muya, W. (2000). "Great expectations as new system seems likely." Daily Nation on web. URL: http://www.nationaudio.com/News/DailyNation/2202000/News59.html (17th April, 2005).

Ojiambo, O (2009). "Quality of Education and its Role in National Development: A Case study of Kenya's Educational Reforms." Kenya Studies Review. KSR Volume 1, Number 1, December 2009.

Otiende, J. et al (1992). Education and Development in Kenya: A Historical Perspective. Nairobi: Oxford University Press.

Otiende, E., Wamahium, P., \& Karagan, M.(1992). Education and development in Kenya: a historical perspective. Nairobi: Oxford University Press.

Owino, C. (1997). "Vocational education in primary schools in Kenya and Tanzania: A comparative study with special reference to Kenya." Eldoret: Moi University (Faculty of education). MA dissertation (unpublished).

Republic of Kenya. (1964). Kenya Education Commission Report, part I. Nairobi: Government Press.

Republic of Kenya. (1976). The National Committee on Educational Objectives and Policies (Gathachi Report). Nairobi: Government Printer.

Republic of Kenya, Ministry of Education. (2012). "Education Reforms - Recommendations" www.education.go.ke /ShowPage.aspx?department=1\&id=1164

Republic of Kenya. (1981). Second university: Report of presidential working party (Mackey Report). Nairobi: Government Printer.

Republic of Kenya. (1983). Presidential committee on unemployment (1982/1983) (Wanjigi Report). Nairobi: Government Printer.

Rharade, A. (1997). "Educational reform in Kenya." Prospects, 27(1). Paris: UNESCO.

Sifuna, D. (1990). Development of Education in Africa: The Kenyan Experience. Nairobi. Initiatives Publishers.

Sifuna, D., Otiende, J. E. (1995). Introduction to History of Education. Nairobi. University of Nairobi Press. 
Simiyu, W. (1990). "Vocational and Technical Education and Training in Kenya: case studies of two exemplary Youth Polytechnics". Montreal: University of McGill: MA dissertation (Unpublished).

Simiyu, J. W. (2001). Factors, which influence the teaching of technical and vocational subjects in primary schools in Uasin Gishu, district. Eldoret: Moi University (Department of educational communication). MA dissertation (unpublished).

Stanfield, J (2005). Kenya's Forgotten Independent school Movement. Oxford. Blackwell Publishing. 
